\title{
THE LEGAL SELF-DETERMINATION OF THE IMPOVERISHED SOCIAL GROUPS' REPRESENTATIVES
}

\section{Bielavina T. I.}

\section{INTRODUCTION}

A special socio-economic structure was generated in the present socioeconomic circumstances against the background of breathtaking transformation in all spheres of social life. On the one hand, it is an excessive enrichment of certain, small part of the population and on the other hand, it is an impoverishment of significant part of the population who find themselves in economically deprived status. The part of Ukrainian society is unprepared psychologically for present changes which cause in ordinary person feelings of uncertainty, anxiety, and a sense of social insecurity.

This issue is particularly important because poverty is now widely spread. The majority of the population is poor including men and women of working age. Moreover, among them, a certain number have higher education and higher qualification. A specific social category of "working poor" was discovered. They receive a payment for their labor that does not secure the needed household income. In addition, the marginal section of the poor on a lowest level was formed including those who have special socio-psychological orientation such as the homeless, the beggars, the homeless children, the former prisoners, the representatives of groups belonging to non-productive subcultures, the poverty-stricken social groups (low-skilled workers with low education, with poor health, etc.).

In their consciousness, the representatives of the economically vulnerable social groups do not hold in a priority the respect and trust for the legal norms and requirements of the law, and the concept of civil rights and freedoms. On the contrary, many of them have a dominant idea that nothing depends on them and that the law is not able to protect them in the face of the new time challenges. The part of the indigent is characterized by a significant deficiency of legal awareness, distorted the legal self-determination, and perverted self-control. The consequences of the legal awareness distortion are the problems with the legal self-identification, his/her distrust to all social institutions, including state and legal ones. The close and complex 
interrelationship occurs between the economic plus legal awareness and the conditions for overcoming the economic deprivation.

It entails the necessity to determine what the factors are and how they influence the process of the legal self-determination of the poverty-stricken social groups' representatives, and groups with low economic status. It requires identifying the role of subjective factors of psychological gravity toward poverty in the legal self-determination of a person with deviations of the legal socialization.

\section{The social-psychological distinctions of the legal consciousness of the poverty-stricken groups' representatives}

The researches of the legal issues of the poverty are characterized by the variety of methodological principles for analysis of the correlation between the society's culture and the social group subculture, and also by the lack of more or less consensual understanding of how "far the person went astray on the way of alienation from the universally accepted norms and values"1,2,3. The numerous studies observe that those individuals who subjectively identify themselves with the poor, defenseless, losers more often excuse themselves for the unlawful inclination, individualism, and destructive emotions ${ }^{4}$. To the large degree that causes the illegal behavior of the individual and also the growth of the resistance to the legal system in society ${ }^{1,3,5}$. In general, the poverty becomes a factor of the human rights violation and an important prerequisite to deficiency of legal awareness, so called "social crudeness of public opinion" of such groups ${ }^{7,8}$.

\footnotetext{
${ }^{1}$ Гилинский Я. Девиантология: социология преступности наркотизма, проституции, самоубийств и других «отклонений» / Я. Гилинский. Девиантология. - СПб.: Издательство «Юридический центр Пресс», 2004. - 520 c.

${ }^{2}$ Ильин И.А. О сущности правосознания / Теория права и государства / И.А. Ильин. - Моск. гос. ун-т им. М.В. Ломоносова. Юрид. фак. - Москва: Зерцало: Система Гарант, 2003. - 398 с.

Петров В. Р. Деформация правосознания граждан России (Проблемы теории и практики): дис. ... канд. юрид. наук: 12.00.01- М. : РГБ, 2002 [Электронный pecypc: http://diss.rsl.ru/diss/ 02/0002/020002597.pdf ]

4 Муздыбаев К. Переживание бедности как социальной неудачи: атрибуция ответственности, стратегии совладания и индикаторы депривации / К. Муздыбаев // Социологический журнал. - 2000. № 3/4. - С. 36 .

5 Гулевич О.А., Голынчик Е.О. Правосознание и правовая социализация. Аналитический обзор / О.А. Гулевич, Е.О. Голынчик. - «Психология». Москва: Международное общество им. Л.С. Выготского. - 2003. - 270 с.

${ }^{6}$ Петровская Т. Соціально-психологічні фактори економічної поведінки / Петровская Т. // Соціальна психологія. - 2004. - № 4(6). - С. 23-35.

Петров В.Р. Деформация правосознания граждан России (Проблемы теории и практики): дис. ... канд. юрид. наук: 12.00.01 - М. : РГБ, 2002 [Электронный pecypc: http://diss.rsl.ru/diss/02/ 0002/020002597.pdf ]

8 Гулевич О.А., Голынчик Е.О. Правосознание и правовая социализация. Аналитический обзор / О.А. Гулевич, Е.О. Голынчик. - «Психология». Москва: Международное общество им. Л.С. Выготского. $-2003 .-270$ с.
} 
The anti-social behavior is often associated with poor people or communities belonging to non-productive subcultures according to economic criterion. Usually, the representatives of the poorest, marginalized groups are related to the crime in its various manifestations, vagrancy, drug addiction, alcoholism, and other deviations. They are the results of isolation from social life and the exclusion from the generally accepted lifestyle which is directed to the socialization, and that separation leads to breaking social bonds or lack of them.

The realities of the current life predetermine a significant distortion of a person's value system, his beliefs, and attitudes. The proper ideas were developed in the researches that discuss the deficiency of the legal awareness of citizens. The generally accepted understanding of such a deformation presupposes the existence of certain legal opinions, knowledge, attitudes, which transformed into non-legal constructions and at the extreme degree of distortion into criminal consciousness. The researchers of legal consciousness suggest different forms of classifications of distortion. For example, Y. Vedernikov emphasizes such forms as legal ignorance, legal idealism, legal nihilism, degeneration, legal dilettantism, and legal doublespeak.

Usually, among the representatives of social groups with the lower economic status, the following widely spread types are recognized: 1) legal ignorance - it is understood as an insufficient level of legal knowledge and attitudes plus the difficulties in legal self-determination. It is a lack of positive and respectful approach to the law and other legal values; 2) legal idealism - it consists in inadequate attitude to the law, and excessive expectations that the adoption of the needed law solves all problems; 3) legal nihilism - it is conscious ignoring of the law's requirements including criminal intent to violate the law, and conviction that person has to be governed not by the law but self-interest; 4) degeneration - it is the lowest level of distortion of the defective legal consciousness to the point that it poses danger to the public. It is characterized by a conscious refusal of the law based on self-interest, cruelty, and greediness 9 .

Y. Gilinsky argues that such measures as raising the quality and standard of living plus the level of education do not per se contribute to reducing the crime or general criminalization of society. The crime is widespread among the well-off and respectable men as well as among the

\footnotetext{
${ }^{9}$ Ведерников Ю.А. Теорія держави та права : навч. посіб. / Ю. А. Ведерніков, В.С. Грекул. - К. : Центр навч. л-ри, 2005. - 224 с.
} 
poor but the object and the means to commit the crime are different. The legal impunity for the violation of the law is more inherent to the affluent men. Such a type of attitude to the law is deeply rooted in strong belief of a person in his own freedom from punishment for the violation either due to force (weapon, organized criminal group), or money (economic status), or power (corruption, social parasitism), or the combination of all these resources ${ }^{10}$.

In her studies on the interaction among delinquents, O. Khorina defined the types of resource interaction as following: altruisticsacrificial - it is sharing one's resources with others; selfish-consumer - it is exploitation of another person's resources; equivalent exchange of resources; destructive-isolation - it is social isolation (neither I nor for me). Most problems arise with the destructive-isolation type of resource interaction when a person suffers from a lack of a certain resource, but can not make a request or accept a resource from another. Such a lack hinders the sharing of the resources and increases the risk of self-destruction ${ }^{11}$.

The economic consciousness of the subject determines the external manifestations of his economic activity and can have a significant impact on its course, results, and consequences. We suppose that people, who have limited access to economic and other resources for achieving their goals, more likely discover that they have a competitive disadvantage comparing to people who are more affluent and have a certain status. If an economically deprived person does not realize his/her resources to succeed he/she is looking for common problems, hostility, and aggression through which he/she exposes the external style of self-regulation, and resorts to self-justification of his/her irresponsibility, lack of initiative, disregard to the requirements of important moral and legal norms, and thus, he/she demonstrates legal nihilism. A recompensed search of faith in goodness partially assists and even faith in an essence of religion helps. For example, it is precisely among representatives of poverty-stricken social groups that "hope for God" dominates significantly as an additional resource for optimizing attitudes and self-esteem of an individual.

\footnotetext{
${ }^{10}$ Гилинский Я. Девиантология: социология преступности наркотизма, проституции, самоубийств и других «отклонений» / Я. Гилинский. Девиантология. - СПб.: Издательство «Юридический центр Пресс», 2004. - 520 c.

11 Хоріна О.І. Дестуктивні моделі міжособових стосунків підлітків. Наукові студії із соціальної та політичної психології: Зб. Статей / АПН України, Інститут соціальної та політичної психології; Редкол.: С.Д. Максименко, М.М. Слюсаревський та ін. - К.: Міленіум, 2008. - Вип. 19 (22). - С. 111-123.
} 
The relationship between law and morality is significant in the legal self-determination process. L. Petrazhitsky is the author of the psychological concept of the law, and he divided the law into two major categories: on the official law and the intuitive law. The official law is authorized by the state. The intuitive law is connected with experiences, morality, and spirituality. He believed that the law is an emotional phenomenon. He argued that "the basis for the intuitive law (legal consciousness) is justice" 12 .

The results of the studies on this topic demonstrated that the concept of "justice" occupies a more important place than legal norms in the legal consciousness among the representatives of poverty-stricken social groups. Weakening the uncritical attitude to legal requirements and sanctions stands in correlation to the degree of agreement with the general principles of morality and justice. The poor more often are guided by moral principles and ethics than other respondents. If the principles of the legal system do not correspond with their value system, moral and ethical norms, then they hold that the laws should be changed.

\section{Social-psychological interdependence between the poverty and legal self-determination process}

An empirical study was aimed at ascertaining the interdependence between the legal self-determination and the level of psychological gravity toward poverty, belonging to a non-productive subculture, identifying the link between objective indicators of the deficit of the economic resource and psychological inclination to poverty. An integrated approach to socio-psychological tools explains the use of methods: theoretical analysis, interviewing, testing, projective techniques, socio-psychological training, game modeling, systematization and synthesis of the data.

At the first step, the selection, approbation, and correction of methodical tools were executed. At the second step, the sociopsychological peculiarities of the legal consciousness and the legal selfdetermination were specified concerning persons who belong to nonproductive subcultures. The poor are attributed to these subcultures. At the third step, correction-development methods were used to optimize the

\footnotetext{
12 Петражицкий Л.И. Теория права и государства в связи с теорией нравственности Л.И. Петражицкий. - СПб.: Издательство «Лань», 2000. - 608 с.
} 
process of the legal self-determination of the poverty-stricken social groups' representatives.

The socio-psychological study tools included: a test for the diagnosis of the personality attitude called "altruism-selfishness" that is aimed at investigating the orientation of personal attitudes; test for the diagnosis of social-psychological activity motivators that was composited on the basis of the motivation theory created by D. McClelland; A. Mehrabians test that is directed towards the identification of affiliation motives; MarloweCrowne approval motivation test. These techniques are borrowed from the collection of psychological tests edited by M.P. Fetyskin ${ }^{13}$

The lifestyle specific character of people with low economic status and their psychological state have been studied by such methods as "Lifestyle self-assessment of people with different economic status", "Typology of subcultures of dissatisfaction" by N. Kalina ${ }^{14}$ and the questionnaire "Psychological gravity toward poverty" by V. Vasutinsky (hereinafter referred to as PGTP) ${ }^{15}$.

One of the purposes of this study was to determine a connection between psychological gravity toward poverty and the peculiarities of the legal self-determination in the formation process of the cognitive, affective and behavioral components of the legal consciousness. It was completed through the studies of the attitudes to the law in the social stratum by interviewing methods, projective techniques, questionnaires in the version of O. Gulevich, O. Golynchik ${ }^{16}$, and questionnaire of PGTP ${ }^{17}$. Also, the "Scale of conscience" composed by V.V. Melnikov, L.T. Yampolsky was used to determine the degree of respect for social norms and ethical requirements: responsibility, integrity, the stability of moral principles ${ }^{18}$. The questionnaire of V.I. Morosanova, that is called "The style of behavior

\footnotetext{
13 Фетискин Н.П. Социально-психологическая диагностика развития личности и малых групп / Фетискин Н.П., Козлов В.В., Мануйлов Г.М. - М.: Изд-во Ин-та Психотерапии, 2002. - 490 с. C. 193-197.

${ }_{14}$ Каліна Н.Ф. и др. Лики ментальности и поле политики: Монография / Н.Ф. Калина, Е.В. Черный, А.Д. Шоркин - К. : Агропромвидав України, 1999. - 184 с., - Библиогр.: С. 167-171.

15 Васютинський В.О. Стиль життя як соціально-психологічна характеристика культури бідності / Васютинський В.О. // Наук. студії із соц. та політ. психології: Зб. статей / НАПН України, Ін-т соц. та політ. психології. - К., 2012. - Вип. 30 (33). - С. 19-32.

${ }^{16}$ Гулевич О.А., Голынчик Е.О. Правосознание и правовая социализация. Аналитический обзор / О.А. Гулевич, Е.О Голынчик. - «Психология». Москва: Международное общество им. Л.С. Выготского.2003. $-270 \mathrm{c}$.

17 Васютинський В.О. Стиль життя як соціально-психологічна характеристика культури бідності / Васютинський В.О. // Наук. студії із соц. та політ. психології: Зб. статей / НАПН України, Ін-т соц. та політ. психології. - К., 2012. - Вип. 30 (33). - С. 19-32.

18 Фетискин Н.П. Социально-психологическая диагностика развития личности и малых групп / Фетискин Н.П., Козлов В.В., Мануйлов Г.М. - М.: Изд-во Ин-та Психотерапии, 2002. - 490 с. C. 193-197.
} 
self-regulation", was applied for studies of various aspects of individual self-regulation ${ }^{19}$. Furthermore, the objective criterion is taken into account, namely, the economic indicator of the income level per family member.

One of the tasks of the studies was to determine the correlative relationship between the data received in the questionnaire of $\mathrm{PGTP}^{20}$ and the results obtained by the methodology of $\mathrm{N}$. Kalina ${ }^{21}$ as well as the degree of conformity of subjective and objective poverty indicators.

In general, 673 people aged 18 to 77 years, with a small prevalence of older women took part in the studies at various stages. They are residents of Kyiv city, and also Zaporizhzhia, Kyiv, Poltava, and Sumy regions. According to the level of material welfare (before the rise of salaries and pensions), the test subjects were distributed as follows: the low level - up to 2 thousand UAH. Monthly income per family member - $43.7 \%$, average - from 2 to 3 thousand UAH. - 24.7\%, high - from 3 thousand UAH. $-31.6 \%$. In line with the results of the questionnaire of PGTP the high level of psychological gravity toward poverty (63.9\%) prevails among people with low economic status, but individuals with high material income have a low level of PGTP (19.4\%, the difference is significant at $\mathrm{p} \leq 0.05)$. The comparison of objective and subjective criteria of poverty has confirmed the close connection between the objective indicators of the material welfare and the psychological gravity toward the poverty of people who choose poverty as a lifestyle.

The selection of the most informative methods under the stated objections was accomplished through interviewing 180 students of the 3-5-year study of economic, pedagogical and law specialties from the three higher institutions of Berdyansk city, and Zaporizhzhia region. The age of respondents ranges from 19 to 23 years. By gender, the respondents were distributed relatively equally with a slight preference for females $(54.4 \%)$. The data obtained have been subjected to correlative and factor analysis. Thus, a final set of methods was defined and it includes such techniques as the test for diagnosis of the personality attitude, namely, "altruismegoism", the A. Mehrabian's test for the identification of the affiliation motives, V. Melnikov's "Scale of conscience", L. Yampolsky, Marlowe-

\footnotetext{
19 Моросанова В.И. Опросник «Стиль саморегуляции поведения» / В.И. Моросанова (ССПМ): Руководство // М.: Когито-Центр, 2004. - 44 с.

${ }^{20}$ Васютинський В.О. Стиль життя як соціально-психологічна характеристика культури бідності / Васютинський В.О. // Наук. студії із соц. та політ. психології: Зб. статей / НАПН України, Ін-т соц. та політ. психології. - К., 2012. - Вип. 30 (33). - С. 19-32.

${ }^{21}$ Каліна Н.Ф. и др. Лики ментальности и поле политики: Монография / Н.Ф. Калина, Е.В. Черный, А.Д. Шоркин - К. : Агропромвидав України, 1999. - 184 с., - Библиогр.: С. 167-171.
} 
Kraune approval motivation test ${ }^{22}$, the multi-layered technique by V. Morosanova or "The style of behavior self-regulation ${ }^{23}$, PGTP test ${ }^{24}$, projective method of O. Gulevich, O. Golynchik ${ }^{25}$, N Kalina's method that is called "Typology of Subcultures of Dissatisfaction" 26.

The application of these methods allowed to determine the construct of moral and legal self-consciousness (motivational-value, cognitive and reflexive components) of persons with various degrees of psychological gravity toward poverty. The research was carried on a sample of 247 respondents aged 18 to 45 and among them were $53.4 \%$ women. Indicators of material well-being were specified showing that $21.4 \%$ of respondents had up to 1 thousand UAH., from 1 to 2 thousand $-22.3 \%$, from 2 to 3 thousand UAH. $-23.7 \%$, from 3 to 4 thousand UAH. $-14.6 \%$, more than 4 thousand UAH. $-17 \%$.

According to the results of the factor analysis of the obtained data, five factors were distinguished (the combined dispersion was 50.6\%), and their content characteristic emphasized the distinctions concerning the rights, morality, justice, self-regulation, and the integrity of individuals who choose the poverty as a lifestyle.

The first single-pole factor is "Responsible efficiency" (contribution to the variance is $11.1 \%$ ). Our study revealed the highest manifestation of the first factor in the group with an income level between "up to 3000" and "more than 3000 " ( $\mathrm{p} \leq 0,1)$. The smallest manifestation of the first factor was in the groups with the lowest and highest level of the income. It paradoxically united the social categories with various economic levels. It appears that "Responsible effectiveness" is the least important for the poorest who believe that nothing depends on them and someone has to take care of them.

The second factor was identified as "Control" (10.3\%). The third and fifth bipolar factors were identified as "Trust - Anxiety" (10.1\%) and

\footnotetext{
22 Фетискин Н.П. Социально-психологическая диагностика развития личности и малых групп / Фетискин Н.П., Козлов В.В., Мануйлов Г.М. - М.: Изд-во Ин-та Психотерапии, 2002. - 490 с. C. $193-197$.

${ }^{23}$ Моросанова В.И. Опросник «Стиль саморегуляции поведения» / В.И. Моросанова (ССПМ): Руководство // М.: Когито-Центр, 2004. - 44 с.

${ }^{24}$ Васютинський В.О. Стиль життя як соціально-психологічна характеристика культури бідності / Васютинський В.О. // Наук. студії із соц. та політ. психології: Зб. статей / НАПН України, Ін-т соц. та політ. психології. - К., 2012. - Вип. 30 (33). - С. 19-32.

${ }^{25}$ Гулевич О.А., Голынчик Е.О. Правосознание и правовая социализация. Аналитический обзор / О.А. Гулевич, Е.О. Голынчик. - «Психология». Москва: Международное общество им. Л.С. Выготского.-2003. -270 с.

${ }^{26}$ Каліна Н.Ф. и др. Лики ментальности и поле политики: Монография / Н.Ф. Калина, Е.В. Черный, А.Д. Шоркин - К. : Агропромвидав України, 1999. - 184 с., - Библиогр.: С. 167-171.
} 
"Altruism - Selfishness" (9\%). Significant differences between the groups with varied income according to the data that indicated the second, third, and fifth factors were not detected.

The fourth bipolar factor was identified as "Justice" $(10,1 \%)$. It showed significant differences between the groups with the income "up to 1000 " and "more than 3000 " ( $\mathrm{p} \leq 0,1)$, and also between the groups with the income "up to 2000" and "more than 3000 " ( $p \leq 0.05)$. The lower is the profit the more important is justice from a subjective point of view. The wealthier people consider themselves free from legal and moral norms. They are less willing to accept them as their duty.

Consequently, the construct of moral and legal self-awareness of individuals with a certain degree of psychological gravity toward poverty focuses on such characteristics as responsibility, control, trust and anxiety, justice, altruism, and selfishness.

The results analysis of the application "Scale of conscience" method on the same sample revealed that persons with a high level of psychological gravity toward poverty $(p \leq 0.05)$ were more conscientious and law-abiding (according to the conformal type). They are characterized by good conscience, a desire to keep to social requirements that is usually united with self-control. Self-control and self-regulation are the most important aspects of the legal self-determination of a person.

The results obtained by "The style of behavior self-regulation" method indicate the development level of individual system of the human activity self-regulation. The average and low general levels of selfregulation $-59.4 \%$ and $33.7 \%$ respectively are more typical for the respondents with low economic resources and a high level of psychological gravity toward poverty. A high level of self-regulation was detected only in $6.9 \%$ of cases.

Therefore, individuals, who suffer from a lack of material resources and demonstrate a willingness to be poor, are characterized by the low ability to self-regulation and reflexivity, conformity, and propensity to manipulate. At the same time, they have the ability to the detailed assessment of the situation, endeavor, and initiative in communication. The persons with an average level of psychological gravity toward poverty can set goals, to plan, to keep a deadline for completing the tasks. They are inherent to psychological flexibility, innovation. 
The belonging of the respondents to the subculture of poverty was confirmed by N. Kalina's "The typology of subcultures of dissatisfaction" method $^{27}$. The studies were carried on a sample of 117 citizens from Kyiv city and Berdyansk, and Zaporizhzhia region aged 18 to 59 years with a small preference of retired women (57.3\%). Among them were unemployed, pensioners, and representatives of different professions. The typology of subcultures of dissatisfaction has been identified based on the scales (according to N. Kalina, p. 113-117). The typology includes six sociotypes: "lucky", "master-happy", "idle-militant", "master-stricken", "idle-downcast", "absurdist". Based on two universal characteristics of the activity, namely, intensity and productivity and their combinations these sociotypes were combined into three groups. The first group comprised "lucky" and "master-happy" sociotypes due to the indicators of intensive and productive activities. It was named "Satisfaction" (28.2\%). The second group was combined based on intensive but unproductive activities. It was called "Psychological protection". It included such sociotypes as "idlemilitant" and "master-stricken" (29.1\%). The third group was called "Pessimism" and was singled out due to the indicators of non-intensive and unproductive activities. It includes such sociotypes as "idle-downcast" and "absurdist" (42.7\%).

Indicators of objective economic status in the isolated groups were distributed in this way: in "the Satisfaction group" the low income have $43.2 \%$ of respondents, the average $-27.0 \%$, the high $-29.7 \%$; in "the Psychological protection group" $44.1 \%$ of respondents gain low income, an average $-23.5 \%$, and a high $-32.4 \%$; in "the Pessimism group" the majority of respondents have a low level of material well-being (55.6\%), the average level has $16.7 \%$ of respondents, and the highest level of income maintain $27.8 \%$ of respondents.

The test of incomplete statements was used to study the attitudes to the law functions, the possibilities of its amendment, the conditions of law observance and the probability of its violation by persons with different economic status. The test was elaborated by O. Gulevich and O. Golynchik ${ }^{28}$ based on a model of legal development. According to this model, there are three types of legal development like law-abiding, law

\footnotetext{
${ }^{27}$ Калина Н.Ф. и др. Лики ментальности и поле политики: Монография / Н.Ф. Калина, Е.В. Черный, А.Д. Шоркин - К. : Агропромвидав України, 1999. - 184 с., - Библиогр.: С. 167-171.

28 Гулевич О.А., Голынчик Е.О. Правосознание и правовая социализация. Аналитический обзор / О.А. Гулевич, Е.О. Голынчик. - «Психология». Москва: Международное общество им. Л.С. Выготского. $-2003 .-270$ c.
} 
support and law-making. Those who are at the first level of the legal development perceive "the law" and "morality" as being inseparable. The norms are observed not based on unconscious acceptance of principles but due to emotional and value attitude to the law and legal sanctions. At the second level, the person abides by the law to meet social expectations. A person at the third level is guided not by the actual laws but the general principles of the legal system's existence (Gulevich).

The test consists of the four incomplete sentences concerning an understanding of the basic functions of the law, the possibility of changing the law, the reasons for the observance of the law, the probability of its violation. Each sentence is accompanied by four variants of answers three of which consistently reflect three types of personal legal development law-abiding, law support and law-making. The fourth option allows completing the sentence with personal opinion. Furthermore, the results obtained from the representatives of all three subcultures of dissatisfaction are compared.

The first incomplete sentence says "The main function of the law is ...". It has the following answers: a) the punishment of people who violate social norms and are dangerous for others; b) a support of the state's vitality, prevention of behavior, aimed at its destruction; c) an advance the life of certain people and the entire state; d) personal view.

The distribution of responses reveals that more than one-third of the representatives of all three groups consider that the main function of the law is the punishment, and abiding by the law is possible only through prohibition. They do not doubt the perfection of the law and are convinced that people comply with the law out of fear of punishment. Their level of legal development is law-abiding.

The relative majority of the representatives of "the Satisfaction group" (44.1\%) consider that the main function of the law is to support the fundamentals of the state. The attitude to the legal requirements reveals that they are considered as the result of the common consent of people, conformism, and the desire to meet social expectations. The response indicators of such groups as "the Psychological protection" (33.3\%) and "the Pessimism" (37.3\%) were slightly lower than the respond indicators of "the Satisfaction group" but in the line with tendency. In general, such attitude characterizes those who are at the level of law support. 
The assessment of the law as a means of advancing the lives of individuals causes skepticism among representatives of all three groups. Comparatively more respondents are in "the Psychological protection group" $(30.3 \%)$ who assume that this is the main function of the law. The relatively high law-making level of legal development in this group can be partially explained by the bigger number $(76.5 \%)$ of people with higher education in this group - in other words, they are more knowledgeable.

The second incomplete sentence says "Changing the law...", and has the following variants of answers: a) is inadmissible under any conditions; b) possible if the law destroys the fundamentals of the state, impedes its development; c) possible, if the law is unfair, and does not correspond to the basic moral norms; d) personal view.

The first variant of the answer was more often chosen by respondents of "the Pessimism group" $(20.0 \%)$. On the contrary, more than half of the representatives of "the Satisfaction group" (61\%) and "the Psychological protection group" (62\%) significantly more than the respondents of "the Pessimism group" (in both cases $\mathrm{p} \leq 0.05$ ) consider that it possible to change the law if it destroys the fundamentals of the state and hinders its development. About two-fifths of respondents in all groups assume the possibility of changing the law if it is unfair. Such results indicate distrust to the existing legal reality that manifests itself in the non-recognition of legal norms, demands, and sanctions since the subjects of such a behavior question the ability of the law to protect rights and freedoms for they do not believe in its justice.

The third incomplete sentence says "People mostly abide by the law because ...", and the test provides the choice from the following variants of answers: a) they fear punishment for violations of the law or want to reap the benefit of abiding in the law; b) they try to be like people around them, and do not want to violate the established rules or try to avoid the chaos that will be resulted from the violation of the law; c) they recognize that in general the law is fair, and corresponds to the basic moral norms; d) personal view.

More than half of the respondents in all three groups choose the first option considering that people are afraid of the punishment for violating the law or expect to reap the benefit of abiding in it. From a quarter to the sixth part of respondents of each group think that people are trying to be like the others, and do not want to violate the established rules or try to 
avoid chaos. This attitude becomes more definite with age. Each third, fourth or fifth respondent depending on the group recognizes that the law is fair and meets moral standards. The significant differences between groups in the evaluation of this test sentence have not been revealed.

According to the data obtained from the response on the fourth test sentence concerning the possibility of breaking the law the respondents quite often hold that it is inadmissible to change the law. Thus, they acknowledge its importance for the regulation of public life. In other words, they are guided by it in their actions and fulfill legal requirements. This opinion is especially popular among the representatives of "the Pessimism group" for half of them hold this view while in the other two groups only a quarter or a third part of respondents $(\mathrm{p} \leq 0,05)$ state it. Significantly fewer respondents suggest the possibility to violate the legal standards for maintaining the fundamentals of the state and its development, but the smallest number of such respondents is in "the Psychological protection group" ( $\mathrm{p} \leq 0,05)$. The majority of respondents see the need to change the law when it is unfair, but such respondents are relatively less in "the Pessimism group" $(\mathrm{p} \leq 0.05)$.

Summing up, we note that the conception of persons with different economic statuses about the interrelation of legal and ethical norms is not homogeneous. The types of perception of legal and ethical norms are determined by the assessment of their goals and effectiveness, and also in conformity with the levels of legal consciousness development like rationalistic, pessimistic, nihilistic, and idealistic. Rationalistic perception that prevails in "the Satisfaction group" is inherent to those who hold that the obedience to the law is necessary since it is a barrier for the destruction of the state fundamentals but it can be passed around if it is unfair. The persons, who perceive the law pessimistically (that attitude characterizes "the Pessimism group"), have uncompromising conception based on the general negative attitude and doubts in the possibility of a fair decision. They hold that the violation of the law is impossible, and abiding by the norms is mandatory. The nihilistic perception (it is inherent to the representatives of "the Psychological Protection group") characterizes those who deny the values of the law and do not believe that through obedience to the law one can establish justice. An idealistic view of the law ("the Psychological Protection group" and "the Pessimism group") specifies those who have a positive attitude to the law and its institutions, 
and believe in the integrity of the guardians of the law and the possibility of fair decisions.

The key to a culture of poverty is an awareness of "deprivation". The test subjects were divided into three groups according to the characteristics of the psychological state: "the Satisfaction group" is characterized by the general satisfaction from life; "the Psychological protection group" is predominantly ambivalent in its experiences; "the Pessimism group" is chiefly characterized by total dissatisfaction. The relationship between affiliation to a certain type of dissatisfaction subculture and the level of legal development is established: law-abiding is inherent to the representatives of "the Psychological protection group" and "the Pessimism group", law support is typical for "the Satisfaction group" and "the Psychological protection group", and law-making is deep-rooted in "the Satisfaction group".

Development of moral and legal orientations of people with the shortage of economic resources occurs in a state of constant socioeconomic inequality, aggravated by the prolonged economic crisis. Moral and legal orientations tend to both constructive and destructive development. The shortage of economic resources causes the subjective restoration of such undesirable norms and values as passivity, dependence, marginal consciousness. Individuals, who subjectively identify themselves as poor, helpless, and losers, more often than others make attempts to justify the unlawful attitudes, degradation, egoism and other negative features and qualities that to large extent lead to unlawful behavior and intensify the illegal attitudes.

\section{Legal self-identification of personality as a sphere of socio-psychological means application for preventing and overcoming the poverty}

One should take into consideration the following issues in determining the paths for positive socio-psychological influence on the legal selfdetermination of persons with low economic status: observance of human rights (provision, protection, participation); attitude to the law, and the legal and moral norms and sanctions; peculiarities of legal deformation and its correction: legal negativism, legal infantilism, legal nihilism.

The usage of corrective measures presupposes the development of the content and procedure for social-psychological training and imitation 
games (modeling law-making projects, rules, principles of coexistence in extreme circumstances) that are the most effective means for optimizing the legal consciousness of those who tend to the poverty plus for measuring the efficiency of their function. This correctional research also included approbation of the questionnaire to measure the action's effectiveness, socio-psychological training, imitation game, systematization and synthesis of the data.

For five studied groups, 129 people were drawn in for participation in activities. Three groups included unemployed who were registered in the Berdyansk city employment center of Zaporizhzhia region: a) in the group for socio-psychological training were 25 people, b) in the group for imitation game were 31 persons, c) control group was made up out of 19 persons. Also, a socio-psychological training for the students of the Kyiv Higher Professional School of Woodworking was organized - for 28 and 26 people accordingly. Participants in corrective-development activities were predominantly in groups with a shortage of economic resources, and also students were from poor families.

In each of the groups, while the control group was excluded, a oneday training or imitation game was organized using the impact program with a general name like "I have the right". The tasks of the sociopsychological training were to form an awareness that civic values and ideals are socially significant, and to enhance the ability to constructively defend personal civil rights; to acquire the knowledge and skills that can change ineffective legal attitudes and behaviour pattern; to actualize the notion of constructive interaction in a group, community, society; to optimize the system of legal and ethical norms expanding the scope of a person with regard to the legal culture.

The training session consisted of eight blocks and was run using exercises on interpersonal and intergroup communication with the implementation of innovative techniques (group discussion, brainstorming, role play, interpersonal training of effective behavior). Such special psychological techniques as self-knowledge, analysis, feedback, and reflection were developed during the training.

The imitation game method was used in one of the groups. It is an effective tool for optimizing the legal consciousness of those who tend to poverty. It is based on modeling projects of law-making, rules, principles of coexistence in extreme circumstances. The special functions of the 
imitation game make it possible to use role-playing techniques as a significant and influential means in correctional work. The interactive potential of the game is revealed through the freedom of participants' actions, submerging in the content of the game, obeying to certain rules, the development of a special, emotionally colored relationship. Scientific literature provides a wide range of game development, describes various aspects of playing activities, suggests how to use their potential, for instance, in the studies of M. Birshtein ${ }^{29}$, A. Verbitsky ${ }^{30}$, R. Zhukova ${ }^{31}$, G. Schedrovitsky ${ }^{32}$, L. Ivanenko ${ }^{33}$, and A. Panfilova ${ }^{34}$.

The imitation game is one of the interactive methods of cooperation in conditions of modeling an imaginary experimental situation (A. Panfilova, 2003). The object of play modeling is to create a situation with uncertain conditions. Thus, its goal is to develop the moral rules of relationship, a collective strategy for survival, a strategy for cooperation.

At the first stage of problematization, the participants had to understand those problems that impede them to put effectively their affairs in order in their lives. At the second stage or the optimization stage, they determined the goal for developing the optimal model of a flourishing community. The third stage is the search for resources that can be used for the realization of the created model and accomplishing the stated tasks. The fourth stage is an organizational design when the participants coordinate the found solutions with the specific conditions answering on the question who exactly and how he/she has to introduce the created model, propositions, and corrections.

The efficacy of the socio-psychological training and imitation game was verified by the interviewing data that were collected before and after classes and the subjective reflections and impressions of participants that they expressed during the questionnaire completion. According to the interviewing data, one significant change was found that freedom became more appreciated (56\% after the training) compared to $16 \%$ before the

\footnotetext{
29 Бирштейн М.М. Советские деловые игры 30-х годов м проблемы развития современной производственной деловой игры // Деловые игры и их программное обеспечение: Материалы конф. М.: ЦЭМИ АН СССР, 1976. С. 194-222.

${ }^{30}$ Вербицкий А.А. Деловая игра как метод активного обучения // «Совр. высш. школа». - 1982. № 3. C. $129-141$.

${ }_{31}$ Жуков Р.Ф. Исследлвание операций в деловых играх. - Л.: ИПК СП, 1980. 84 с.

32 Щедровицкий П.Г. К анализу топики организационно-деятельностных игр. - М.: ВНИСИ, 1987. $-43 \mathrm{c.}$

${ }^{33}$ Иваненко Л.Н. Имитационные игры в условиях массового эксперимента (принципы и практика) // Кибернетика. - 1982. № 4. С. 122-125.

34 Панфілова А.П. Игротехнический менеджмент. Интерактивные технологии для обучения и организационного развития персонала: Уч. пос. / А.П. Панфілова. - СПб:ИВЭСЭП, 2003. - 536 с.
} 
training $(p \leq 0.05)$. Several positive changes in the legal self-determination have been observed as a trend, for example, the value of the law and the trust in the law has been increased (from 22\% to 40\%) and (from 62\% to $70 \%$ ) accordingly. Also, the association of the law with the notion of civic duty has been strengthened (from $48 \%$ to $60 \%$ ) and in the same manner with justice (from 56\% to 60\%). The indicators of independence in solving life problems became more evident. In the control group, there were no apparent changes. Positive changes have been observed in the civic consciousness of the school students: the number of those, who are proud to be the citizens of Ukraine, grew (from $41 \%$ to $67 \%$ ), also the number of those, who chose Ukraine as a country of residence, increased (from $48 \%$ to $68 \%$ ), (in both cases $\mathrm{p} \leq 0.05$ ).

Some special results were obtained that reflect the positive changes in the subjects' legal self-determination: the basal trust in people and society has been strengthened; the importance of such values as "freedom", "law" and "trust" for moral and legal guidelines has been increased; an awareness of the role of law in public life has been deepened.

\section{CONCLUSIONS}

The legal self-determination of persons with low economic status and different levels of psychological gravity toward poverty is performed in the formation process of the cognitive, affective and behavioral components of the legal consciousness. In the process of the legal self-determination, the essence of the legal norms of society is realized. During this process one perceives the legal phenomena, the representations (cognitive component), feelings that reflect the attitude of the people and social communities to the existed or desired legal reality plus to the behavior of people in the legal sphere (affective component). Equally, the formation of a program of the purposeful and law-abiding activities (the behavioral component) is happening.

It has been determined that those, who subjectively identify themselves with the poor, defenseless, losers, more often excuse themselves for the unlawful inclination, individualism, and destructive emotions. To the large degree that causes the illegal behavior of the individual and also the growth of the resistance to the legal system in society. Such attitudes as fatal hopelessness without any prospects, dependence, and state of being oppressed with low motivation to work and 
achievements, inability to plan are inherent and predominant to them. Their desire to change the surrounding world, the sphere of social relationships is also caused by distorted, false interest. It can be contrary to the ideals, values, and goals of society, and in the contradiction between social and personal interests. In general, the poverty functions as a factor of the human rights violation. The poverty comes out in a form of important precondition for the deformation of a person's legal consciousness; it is "a social primitivism of social thought".

The construct of moral and legal self-consciousness of persons with a certain degree of psychological attraction to the poverty is determined, and components of which are the following: motivational-value, cognitive and reflexive components. In the results of these studies, it has been concluded that violations or "defects" of the legal consciousness are generated by the real-life socio-economic conditions in which the legal socialization goes on.

General efforts are important when they are directed at the development of a personal resource attitude to all kinds of circumstances and situations especially in positions of uncertainty. The resource should be understood as a personal ability to make optimal use of the internal potencies, the ability to mobilize them at any time, and the ability to efficiently operate them based on the opened possibility for usage also external resources. Any kind of situation either internal or external consists of conditions and means. The resource attitude to the situation allows us to consider any conditions as a means for usage.

The application of socio-psychological means and methods for a correctional influence provides the optimization of the legal consciousness and the process of the legal self-determination of persons with a shortage of economic resources and representatives of the impoverished social groups.

\section{SUMMARY}

The publication (in the section) deals with the socio-psychological peculiarities of the legal consciousness and the legal self-determination of the social group' representatives that have a low economic status in the conditions of current economic, political and legal transformation. The part of these social categories is characterized by the deformation of the legal consciousness, the distorted legal self-determination, the false selfregulation, and the distrust to the state legal institutions, civil rights, and freedoms. 
The socio-psychological factors of the legal self-determination are established. Those components that caused the distortion of the legal socialization and the system of self-regulation of a person are determined. The role of subjective factors of psychological gravity toward poverty is ascertained. It is determined that "defects" of the legal consciousness are generated by real-life socio-economic conditions in which legal socialization goes on.

The research demonstrates that for solving the addressed issues it is important to use correctional, developmental, and informative methods for optimizing the process of the legal self-determination of social groups' representatives that are poor, for development of the resource attitude of the person to different conditions and circumstances, situations of uncertainty, and the ability to apply the effective coping strategies.

\section{REFERENCES}

1. Бирштейн M.M. Советские деловые игры 30-х годов м проблемы развития современной производственной деловой игры // Деловые игры и их программное обеспечение: Материалы конф. М.: ЦЭМИ АН СССР, 1976. С. 194-222.

2. Васютинський В.О. Стиль життя як соціально-психологічна характеристика культури бідності / Васютинський В.О. // Наук. студії із соц. та політ. психології: Зб. статей / НАПН України, Ін-т соц. та політ. психології. - К., 2012. - Вип. 30 (33). - С. 19-32.

3. Ведерников Ю.А. Теорія держави та права : навч. посіб. / Ю.А. Ведерніков, В.С. Грекул. - К. : Центр навч. л-ри, 2005. - 224 с.

4. Вербицкий А.А. Деловая игра как метод активного обучения // «Совр. высш. школа». - 1982. № 3. С. 129-141.

5. Гилинский Я. Девиантология: социология преступности наркотизма, проституции, самоубийств и других «отклонений» / Я. Гилинский. Девиантология. - СПб.: Издательство «Юридический центр Пресс», 2004. - 520 с.

6. Гулевич О.А., Голынчик Е.О. Правосознание и правовая социализация. Аналитический обзор / О.А. Гулевич, Е.О. Голынчик. «Психология». Москва: Международное общество им. Л.С. Выготского. $-2003 .-270$ с.

7. Жуков Р. Ф. Исследлвание операций в деловых играх. - Л.: ИПК СП, 1980. 84 с. 
8. Иваненко Л. Н. Имитационные игры в условиях массового эксперимента (принципы и практика) // Кибернетика. - 1982. № 4. C. $122-125$.

9. Ильин И.А. О сущности правосознания / Теория права и государ-

ства / И.А. Ильин. - Моск. гос. ун-т им. М.В. Ломоносова. Юрид. фак. - Москва: Зерцало: Система Гарант, 2003. - 398 с.

10. Каліна Н.Ф. и др. Лики ментальности и поле политики: Монография / Н.Ф. Калина, Е.В. Черный, А.Д. Шоркин - К. : Агропромвидав України, 1999. - 184 с., - Библиогр.: С. 167-171.

11. Моросанова В.И. Опросник «Стиль саморегуляции поведения» / В.И. Моросанова (ССПМ): Руководство // М.: КогитоЦентр, 2004. - 44 с.

12. Муздыбаев К. Переживание бедности как социальной неудачи: атрибуция ответственности, стратегии совладания и индикаторы депривации / К. Муздыбаев // Социологический журнал. - 2000. - № 3/4. - С. 36.

13. Панфилова А.П. Игротехнический менеджмент. Интерактивные технологии для обучения и организационного развития персонала: Уч. пос. / А.П. Панфілова. - СПб:ИВЭСЭП, 2003. $-536 \mathrm{c}$.

14. Петражицкий Л.И. Теория права и государства в связи с теорией нравственности / Л.И. Петражицкий. - СПб.: Издательство «Лань», 2000. - 608 с.

15. Петров В.Р. Деформация правосознания граждан России (Проблемы теории и практики): Дис. ...канд. юрид. наук: 12.00.01 M. : РГБ, 2002 [Электронный pecypc: http://diss.rsl.ru/diss/02/0002/ 020002597.pdf ]

16. Петровская Т. Соціально-психологічні фактори економічної поведінки / Петровская Т. // Соціальна психологія. - 2004. - № 4(6). C. $23-35$.

17. Фетискин Н.П. Социально-психологическая диагностика развития личности и малых групп / Фетискин Н.П., Козлов В.В., Мануйлов Г.М. М.: Изд-во Ин-та Психотерапии, 2002. - 490 с. C. 193-197.

18. Хоріна О.І. Дестуктивні моделі міжособових стосунків підлітків. Наукові студії із соціальної та політичної психології: 
3б. Статей / АПН України, Інститут соціальної та політичної психології; Редкол.: С.Д. Максименко, М.М. Слюсаревський та ін.К.: Міленіум, 2008. - Вип. 19 (22). - С. 111-123.

19. Щедровицкий П.Г. К анализу топики организационнодеятельностных игр. - М.: ВНИСИ, 1987. 43 с.

Information about the author: Bielavina T. I. $\mathrm{PhD}$ in Psychology, Associate Professor at the Department of Psychology and Pedagogy of the Scientific and Humanitarian Institute of the V. I. Vernadsky Taurida National University 